\title{
Interactions between Schwann and olfactory ensheathing cells with a starch/polycaprolactone scaffold aimed at spinal cord injury repair
}

\author{
Nuno A. Silva, ${ }^{1,2,3}$ Rui A. Sousa, ${ }^{1,2}$ Ana O. Pires, ${ }^{2,3}$ Nuno Sousa, ${ }^{2,3}$ \\ António J. Salgado, ${ }^{2,3 *}$ Rui L. Reis ${ }^{1,2 *}$ \\ 13B's Research Group, Biomaterials, Biodegradables and Biomimetics, University of Minho, Headquarters of the European \\ Institute of Excellence on Tissue Engineering and Regenerative Medicine, AvePark, 4806-909 Caldas das Taipas, \\ Guimarães, Portugal \\ ${ }^{2}$ ICVS/3B's, PT Government Associate Laboratory, Braga/Guimarães, Portugal \\ ${ }^{3}$ Life and Health Sciences Research Institute (ICVS), School of Health Sciences, University of Minho, \\ Campus de Gualtar, 4710-057 Braga, Portugal
}

Received 29 July 2011; revised 15 September 2011; accepted 26 September 2011

Published online in Wiley Online Library (wileyonlinelibrary.com). DOI: 10.1002/jbm.a.33289

\begin{abstract}
Spinal cord injury (SCI) represents a major world health problem. Therefore it is urgent to develop novel strategies that can specifically target it. We have previously shown that the implantation of starch-based scaffolds (SPCL) aimed for spine stabilization on $\mathrm{SCl}$ animals leads to motor skills improvements. Therefore, we hypothesize that the combination of these scaffolds with relevant cell populations for $\mathrm{SCl}$ repair will, most likely, lead to further improvements. Therefore, in this work, the ability of SPCL scaffolds to support the 3D culture of olfactory ensheathing cells (OECs) and Schwann cells (SCs) was studied and characterized. The
\end{abstract}

results demonstrate for the first time that SPCL scaffolds were able to support the growth and migration of OECs and SCs. Moreover, the results indicate that two weeks of in vitro culture is the ideal time to reach a high number of transplantable cells. Future work will focus on the spine stabilization of $\mathrm{SCl}$ animals using SPCL scaffolds loaded with OECs or SCs for $\mathrm{SCl}$ regeneration. $\odot 2011$ Wiley Periodicals, Inc. J Biomed Mater Res Part A: 00A: 000-000, 2011.

Key Words: bioengineering, scaffolds, spinal cord injury, starch, trophic support

How to cite this article: Silva NA, Sousa RA, Pires AO, Sousa N, Salgado AJ, Reis RL. 2011. Interactions between Schwann and olfactory ensheathing cells with a starch/polycaprolactone scaffold aimed at spinal cord injury repair. J Biomed Mater Res Part A 2011:00A:000-000.

\section{INTRODUCTION}

Motivated by the physical consequences of the World War II, the era of cell transplantation began with the landmark work of Georges Mathé, which transplanted bone marrow to six persons exposed to high doses of radiation. ${ }^{1}$ More than 60 years later the hematopoietic stem cell transplantation still is the only one used in clinical practice. Nevertheless, cell transplantation approaches are, since then, being extensively investigated for a wide range of diseases/injuries. In the particular case of spinal cord injuries, a condition that affect millions all over the world, ${ }^{2}$ two kinds of transplanted cells gain ground when compared to the others. Olfactory ensheathing cells (OECs), obtained from olfactory bulbs or nasal mucosa, and Schwann Cells (SCs), found in the peripheral nervous system, have shown to promote neuronal repair, remyelination, and functional recovery after trans- plantation into the spinal cord..$^{3-7}$ Both cell types are known to express similar molecular markers, such as p75 and S100 and to display a similar morphological phenotype in culture $^{8,9}$ However, contrasting with SCs, which are largely involved in myelination and repair of peripheral nerve fibers, the OECs are known to provide support and guidance to the growth of newly formed axons from the olfactory mucosa to the olfactory bulbs. Moreover, they are also known to be able migrate through the glial scar. ${ }^{10}$

Recent modest results of clinical trials ${ }^{11,12}$ emphasize the need of further studies to understand the mechanism of action and transplantation of these cells. One of the problems associated with cell transplantation therapies is cell survival in vivo, since extensive cell death is usually observed after transplants. ${ }^{13,14}$ This fact is mainly related with the lack of matrix support of transplanted cells, as well

*These authors share senior authorship.

Correspondence to: A. J. Salgado; e-mail: asalgado@ecsaude.uminho.pt (or) R. L. Reis; e-mail: rgreis@dep.uminho.pt

Contract grant sponsors: Portuguese Foundation for Science and Technology, Science 2007 Program; contract grant numbers: SFRH/BD/40684/ 2007, SFRH/BD/33900/2009

Contract grant sponsors: Foundation Calouste de Gulbenkian, European FP7 Project Find and Bind; contract grant number: NMP4-SL-2009229292 
as the inflammation in the local of injury. ${ }^{15}$ For these reasons, we propose the delivery of cells within a scaffold that is not implanted directly in the injury site, thus avoiding the cell death by the lack of matrix support and decreasing the effects of inflammation on the fate of transplanted cells. Hence, within this work, we tested the ability of a previous developed and characterized natural starch-based scaffold (SPCL, starch poly- $\varepsilon$-caprolactone) ${ }^{16}$ to support the 3D culture of OECs and SCs. We have previously shown significant motor recovery in Spinal cord injury (SCI) animals due the spine stabilization by using the above-referred scaffolds. ${ }^{17}$ Moreover, it was previously demonstrated that OECs and SCs are able to secrete neurotrophic factors such as nerve growth factor, brain-derived neurotrophic factor, and glia cell line-derived neurotrophic factor. ${ }^{18,19}$ Additionally, the secretome of these two cells has previously shown to have a positive effect on axonal growth both in vitro ${ }^{20-22}$ and in vivo. ${ }^{23-25}$ Therefore, the presence of these cells on the areas of the scaffold, which face the spinal cord, will allow a localized deliver of neurotrophic factors to the injured area, fostering regeneration to occur. In this sense, combining the secretome effects of OECs and SCs with the previously observed beneficial effects of spine stabilization provided by the SPCL scaffolds implantation may lead to further locomotory recovery.

To do so, we first need to figure out if it is possible to culture OECs and SCs on the SPCL scaffolds. Therefore, in this report we assessed the proliferation, metabolic activity, adhesion, morphology, and distribution of primary OECs and SCs when cultured in a 3D fashion on SPCL scaffolds. The results revealed that SPCL scaffolds were able to support the growth and migration of both OECs and SCs. Moreover, we determined that two weeks of in vitro preincubation is the ideal time to achieve a higher cell density on these scaffolds.

\section{MATERIALS AND METHODS}

\section{Semi tubular SPCL scaffolds development}

The SPCL scaffolds were developed as previously reported by Silva et al. ${ }^{16}$ Briefly, porous sheets featuring interfilament orientations of $90^{\circ}$ were produced by 3D plotting, a rapid prototyping technology (Bioplotter ${ }^{\circledR}$, Envisiontec $\mathrm{GmbH}$ ). Tubular scaffolds were obtained by rolling up porous sheets around a cylinder and subsequent heat treatment at $65^{\circ} \mathrm{C}$ during 30 min for inducing the adhesion between filaments. Two different porous tubular scaffold designs were obtained featuring a single or double layer, further referred as 90/1 and $90 / 2$ for structures with one or two layers, respectively. After being processed, to acquire semi tubular form, the tubular scaffolds were cut in the middle with the aid of a blade.

\section{Scanning electron microscope (SEM) analyses}

Scanning electron microscopy (SEM) was used for analysis of morphology of the different SPCL tubular scaffolds. For this purpose, all samples were coated with $\mathrm{Au} / \mathrm{Pd}$ via ion sputtering prior to observation in a Stereoscan 360 SEM (Leica Cambridge, Cambridge, United Kingdom).

\section{Cell culture}

Isolation and culture of OECs. OECs were harvested from olfactory bulbs of 4-days-old Wistar rats, according to the protocol described by Ramón-Cueto and Nieto-Sampedro ${ }^{26}$ Briefly, upon dissection, all meninges were removed and the tissue was digested with $0.125 \%$ Collagenase (Sigma) for $20 \mathrm{~h}$ at $37^{\circ} \mathrm{C}$. The digested tissue was mechanically dissociated with a pipette and then filtrated through a 70 $\mu \mathrm{m}$ cell strainer (BD Falcon). After centrifugation at 1000 rpm for $10 \mathrm{~min}$, cells were resuspended and plated in uncoated plates for $18 \mathrm{~h}$. A posterior change to uncoated plates for $36 \mathrm{~h}$ was made, as it is expected that most of the fibroblasts and astrocytes will attach in the first and second period, respectively. Finally, cell suspensions were transferred to poly-D-lysine treaded flasks and cultured in DMEM/F12 (Gibco) with $10 \%$ of FBS (Gibco) and $1 \%$ of antibiotic-antimycotic solution (Sigma) at $37^{\circ} \mathrm{C}$ and $5 \% \mathrm{CO}_{2}$ $(\mathrm{v} / \mathrm{v})$. OECs were then enriched by the supplementation with Bovine Pituitary Extract ( $5 \mu \mathrm{g} / \mathrm{mL}$, Gibco) and Forskolin $(2 \mu \mathrm{g} / \mathrm{mL}$, Sigma $)$. Cells were seeded into the scaffolds at passage 2; being that no trypsin was used and cells were detached using a cell scrapper.

Isolation and culture of SCs. SCs were obtained from sciatic nerves of 4-weeks-old male Wistar rats, according to the protocol described by Mauritz et al. ${ }^{27}$ Upon dissection, sciatic nerves were cut into three fragments each and incubated in DMEM-F-12 (Gibco no.11320-074), with 10\% Fetal Bovine Serum (FBS, Gibco 10106-169), 1\% Penicillin-Streptomycin antibiotic (Pen-Strep, Gibco no.15140-148), Forskolin $(2 \mu \mathrm{g} / \mathrm{mL}$, Sigma), and Bovine Pituitary Extract (5 $\mu \mathrm{g} /$ $\mathrm{mL}$, Gibco). Following 7 days of incubation at $37^{\circ} \mathrm{C}$ and $5 \%$ $\mathrm{CO}_{2}$, the nerve fragments were enzymatically dissociated with Collagenase solution (320 U/mL; Sigma no. C0130-1G) containing $5 \mathrm{U} / \mathrm{mL}$ of DNase (Worthington Lot 51M5139) for $20 \mathrm{~h}$. After mechanical dissociation, the collagenase was removed by repeated centrifugations. Cells were then allowed to grow in poly-D-lysine coated flasks. As for OECs, SCs were also seeded into the scaffolds at passage 2 .

\section{Immunocytochemistry}

Immunostaining was performed as follows. SC or OEC-covered cover-slips were fixed in $4 \%$ paraformaldehyde for $20 \mathrm{~min}$ and then washed with PBS. After cell blocking by treating them with $10 \%$ of FCS in PBS (Gibco) for $1 \mathrm{~h}$, Rabbit anti-S100 primary antibody (Invitrogen) was incubated for $1 \mathrm{~h}$. After washing with PBS, cells were exposed to the secondary antibody Alexa Fluor 488 rabbit anti-rat IgG (Molecular Probes) for $1 \mathrm{~h}$. Finally, cell nuclei were counterstained with DAPI (1 $\mu \mathrm{g} / \mathrm{mL}$, ThermoScientific) for $5 \mathrm{~min}$ and washed with PBS. Primary antibody was omitted to produce negative controls. Samples were observed under an Olympus BX-61 Fluorescence Microscope (Olympus).

\section{Seeding of OECs or SCs on SPCL scaffolds}

To ensure adherence of cells, SPCL scaffolds were coated with poly-L-lysine before cell seeding. Cells were centrifuged at $1200 \mathrm{rpm}$ for $5 \mathrm{~min}$ and then resuspended in a small 
volume of medium to yield a solution with a density of $5 \times$ $10^{4}$ cell/10 $\mu \mathrm{L}$. Subsequently, scaffolds were transferred to empty wells and $10 \mu \mathrm{L}$ of cell suspension were dropped on the top of the inner lumen of the semi tubular scaffolds. After an incubation of $2 \mathrm{~h}$ in a humidified atmosphere at $37^{\circ} \mathrm{C}$ and $5 \% \mathrm{CO}_{2}$, SPCL scaffolds were transferred to new wells containing complete medium (for composition details refer to OECs or SCs cell culture section) and incubated for 2, 7, 14 , and 21 days for the in vitro assays.

\section{Proliferation evaluation}

In the time points mentioned above, proliferation, through double-stranded DNA quantification, was assessed. The fluorescent dye Picogreen was used to acquire the total amount of dsDNA. ${ }^{28}$ Briefly, after cell lysis by osmotic and thermal shock three components of QuantiT ${ }^{\mathrm{TM}}$ PicoGreen dsDNA Assay Kit (Invitrogen), Tris-HCl-EDTA (50\%), Picogreen dye (35.45\%), and cell lysated (16.35\%), were mixed in an opaque 96 well plate. The fluorescent intensity, proportional to the amount of dsDNA, was measured at an excitation wavelength of $485 / 20 \mathrm{~nm}$ and at an emission wavelength of $528 / 20 \mathrm{~nm}$, in a microplate reader (Bio-Tek). The dsDNA concentration for triplicates of each sample $(n=3)$ was calculated using a standard curve relating quantity of dsDNA and fluorescence intensity.

\section{Metabolic activity assay}

Cell viability was measured using the CellTiter $96{ }^{\circledR}$ Aqueous One Solution Cell Proliferation Assay (Promega). This assay is based on the bioreduction of a tetrazolium compound (MTS), into a water-soluble brown formazan product. This conversion is accomplished by NADPH or NADH production by the dehydrogenase enzymes in metabolically active cells. Complete culture medium was replaced by standard DMEM/F12 medium containing MTS in a 5:1 ratio and incubated in a humidified atmosphere at $37^{\circ} \mathrm{C}$ and $5 \% \mathrm{CO}_{2}$. After $3 \mathrm{~h}$ of incubation, the optic density for triplicates of each sample $(n=3)$ was measured at $490 \mathrm{~nm}$ in a microplate reader.

\section{Assessment of cell adhesion, morphology, and distribution}

At each defined time culture period, the SPCL scaffolds were fixed with $4 \%$ of paraformaldehyde for $30 \mathrm{~min}$ at room temperature. Then, $0.1 \mu \mathrm{g} / \mathrm{mL}$ of Phalloidin (Sigma) was added to the cells during $30 \mathrm{~min}$. After washing three times with PBS, cell nuclei were counterstained with DAPI (1 $\mu \mathrm{g} / \mathrm{mL}$, ThermoScientific) for $5 \mathrm{~min}$. The SPCL scaffolds were then observed by confocal microscopy (Olympus).

\section{Statistical analysis}

To assess the statistical differences on metabolic activity and proliferation of OECs and SCs, a "two way ANOVA" test was performed followed by a Bonferroni post-test. Statistical significance was defined for $p<0.05$.

\section{RESULTS AND DISCUSSION}

Ensure cell survival in vivo is one of the problems associated with cell transplantation therapies, since extensive cell death is usually observed after transplants. ${ }^{13}$ The lack of matrix support, ischemia, and local inflammation are some of the factors related with poor cell survival after cell based therapies. ${ }^{15}$ Typical cells preparations for injection imply enzymatic digestion of the matrix. When cells that normally grow in attachment are kept in suspension, a pathway of cell death called anoikis is initiated. ${ }^{29}$ Anoikis, a Greek word for homelessness, is described in cell biology as programmed cell death generated by loss of matrix attachments. ${ }^{30}$ In addition, it is well known that after SCI ischemia and inflammation occur. ${ }^{31}$ These two events generate oxygen free radicals and inflammatory cytokines that can directly damage graft cells via cell membrane damage or trigger signaling pathways that result in caspase activation and cell death. ${ }^{15}$ To cell-based regenerative medicine approaches become a successful therapy, these issues should be addressed. Okano and coworkers ${ }^{32,33}$ proposed the use of cell sheets, avoiding in this way the loss of cell matrix support. Others targeted specific molecular pathways aimed at cell death blockage. ${ }^{34}$ We consider that the delivery of cells, with a trophic ability, within a scaffold that is not implanted directly in the injury will avoid the cell death by anoikis and decrease the effects of inflammation on the fate of transplanted cells.

We have recently shown that the spine stabilization by SPCL scaffolds implanted in the vertebral column of SCI rats lead to significant improvements. ${ }^{17}$ However, the spine stabilization alone will not successfully treat the injured animals, and therefore further actions are needed to repair the spinal cord. Thus, in this work, we investigated the ability of SPCL scaffolds to support cells aimed for SCI repair. In this way, the scaffolds will act as a stabilization device and at same time will allow a localized deliver of neurotrophic factors to the injured spinal cord produce by the OECs or SCs.

\section{D culture of OECs on SCPL scaffolds}

OECs and SCs were analyzed, prior seeding on SPCL scaffolds, by immunocytochemistry against S100 receptor [Fig. 1(a,b)]. Subsequently, cells were seeded in the inner core of SPCL scaffolds with one layer [90/1, Fig. 1(c)] or two layers [90/2, Fig. 1(d)]. Cell adhesion, migration, proliferation, and metabolic activity were assessed 2, 7, 14, and 21 days after the seeding.

The quantification of dsDNA revealed a significant increase of cell proliferation from day 2 to day 21, both on single and on double layer SPCL scaffolds [Fig. 2(a)]. Furthermore, only at the second day of culture, the quantity of OECs on single layer scaffolds is significantly higher than in double layer scaffolds, demonstrating a more efficient cell seeding on $90 / 1$ scaffolds. Interesting, either for $90 / 1$ or for $90 / 2$ scaffolds, the quantity of dsDNA did not increase from day 2 to 1 week in culture, which indicates that these cells need a time to adapt to the new 3D surface. Moreover, cells cultured on single layer scaffolds did not presented 

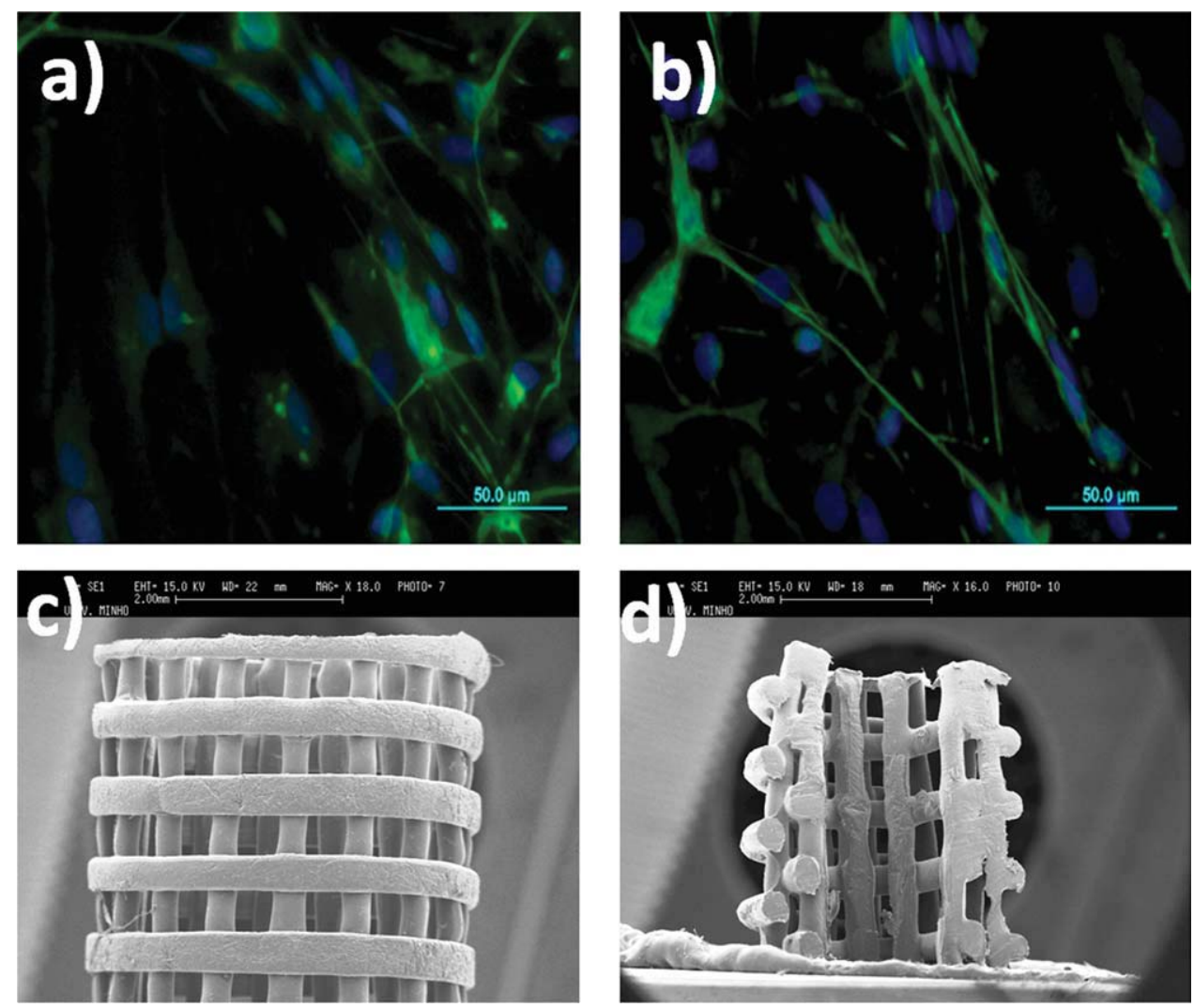

FIGURE 1. Cells and scaffolds before the 3D cultured. The presence of OECs (a) and SCs (b) after cell isolation was confirmed by immunocytochemistry against S-100 protein (green) and nuclei counterstained with DAPI (blue). OECs and SCs were then seeded on the inner core of single (c) or double (d) layer SPCL scaffolds. [Color figure can be viewed in the online issue, which is available at wileyonlinelibrary.com.]

significant cell proliferation between 2 and 3 weeks. On the contrary, on 90/2 scaffolds dsDNA significant increases between 2 and 3 weeks were observed. These differences can be explained by the lower porosity of the $90 / 2$ scaffolds. We have previously reported differences in the porosity of single and double layer scaffolds, being 90/2 scaffolds $15 \%$ less porous than the $90 / 1$ ones. ${ }^{16}$ Therefore, in this condition the cells need more time to reach the confluence. The dsDNA quantification results are in concordance with the measured metabolic activity of OECs [Fig. 2(b)], which from day 2 to day 21 increased significantly on both types of scaffolds. Moreover and up to 14 days in culture, OECs seeded on 90/1 scaffolds showed a statistically higher metabolic activity than the ones seeded in 90/2 scaffolds. As referred before the cell seeding was more efficient on these scaffolds than on the $90 / 2$ ones, a fact that is closely related with these observations, as the initial cell densities would be necessarily different in both. Then, again, the metabolic activity is significantly different between 2 and 3 weeks for double layer scaffolds but not for single layer.

The assessment of migration, adhesion and morphology of OECs by confocal microscopy showed a low efficiency on cell seeding [Fig. 2(c,d), 48 h]. However, over time the OECs successfully colonized the entire SPCL fibers, showing that these cells are capable to migrate and grow in a 3D manner on SPCL scaffolds [Fig. 2(c,d)]. Moreover, after 2 weeks, it was possible to observe the typical spindle-shaped morpho- logy of OECs, which confirmed how well adapted the cells were. Finally, it is possible to confirm that in $90 / 1$ scaffolds cells were confluent at 2 weeks, but for $90 / 2$ the confluence was only reached at 3 weeks. All of the tests indicated that OECs culture on SPCL scaffolds with one or two layers should be implanted in animals after 2 or 3 weeks of in vitro culture.

\section{D culture of SCs on SCPL scaffolds}

Contrasting with OECs, SCs adapted faster on the rigid 90/2 scaffold than in the more porous 90/1 scaffold. dsDNA quantification test revealed that as OECs, the SCs also significantly increased the number of cells from day 2 to day 21 in both types of scaffolds [Fig. 3(a)]. Again, as happened with OECs, the SCs also took around one week to adapt to the new surface, since no significant differences were detected between 2 days and 1 week of culture. However, and in contrast to OECs, the quantity of dsDNA on SCs culture is always higher in the double layer scaffolds, showing that these cells were better adapted to $90 / 2$ scaffolds. Interestingly, cell proliferation stops at 2 weeks for both types of scaffolds, indicating that the implantation of SPCL scaffolds with SCs should be done after around 2 weeks of in vitro culture. By analyzing the metabolic activity of SCs cultured on SPCL scaffolds [Fig. 3(b)] it was possible to confirm that the cells took around 1 week to be adapted to the scaffold (no differences between 2 days and 1 week). No differences 

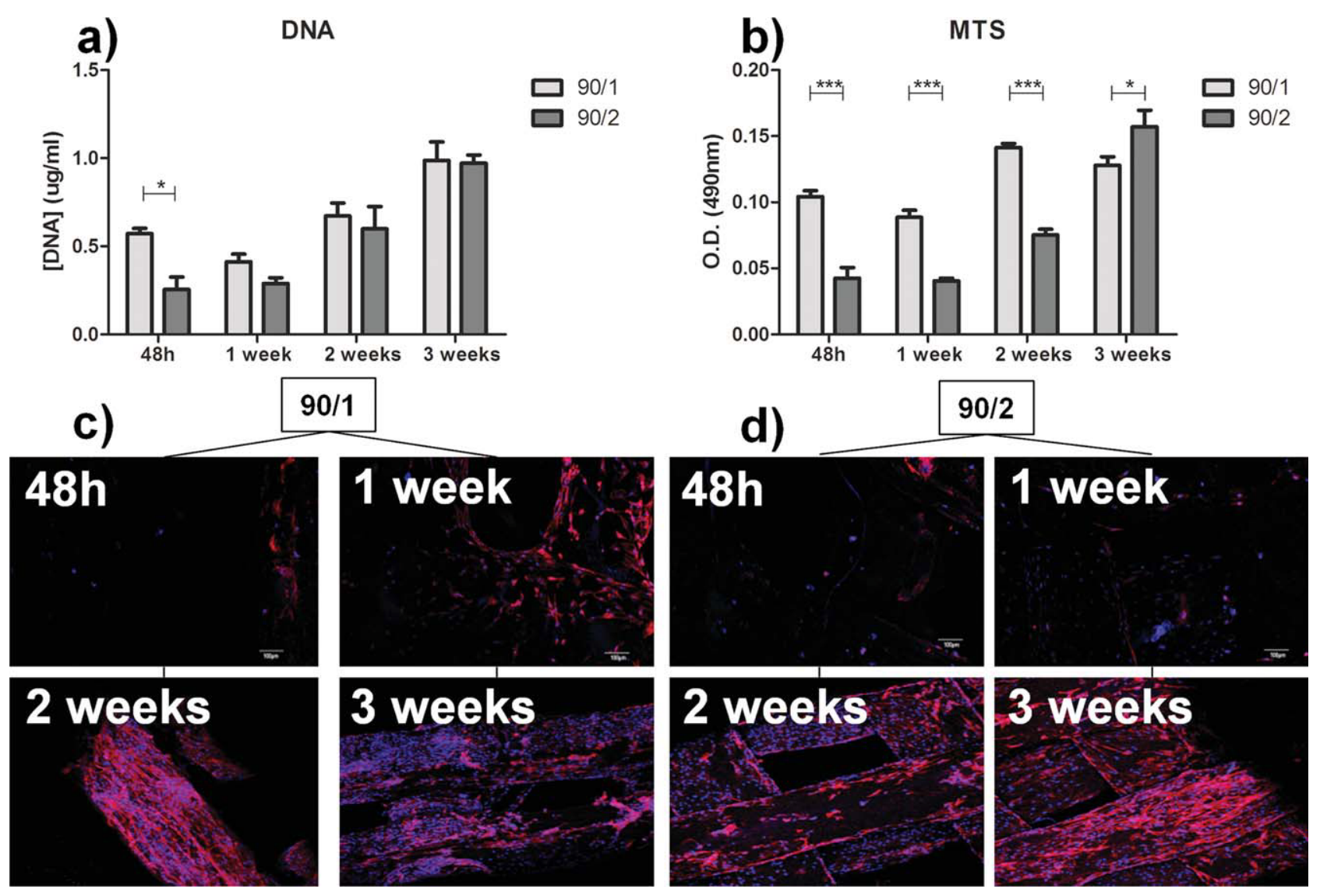

FIGURE 2. 3D cell culture of OECs on SPCL scaffolds. A significant $(p<0.05)$ overall increase over time was observed either for (a) dsDNA quantification or (b) MTS test. Cellular adhesion, distribution, and morphology were assessed by cytoplasmic staining with phalloidin (red) and nuclei counterstained with DAPI (blue), followed by confocal observation. Despite of a low efficient cell seeding (48 h), OECs were able to migrate and colonize all fibers of both single (c) and double (d) layer SPCL scaffold. Values are shown as mean \pm SEM $(n=3)$. [Color figure can be viewed in the online issue, which is available at wileyonlinelibrary.com.]

were found between weeks 2 and 3 , reinforcing the idea that these cells should only be cultured on the scaffolds for periods up to two weeks before transplantation. It is surprising, although the absence of significant differences between the one and two layers scaffolds; in other words, it seems that despite the lower number of cells in the onelayer scaffolds, they were more metabolically active than the cells from two layers, a difference that may be due to the higher porosity of the one-layer scaffolds.

The assessment of migration, adhesion, and morphology of SCs by confocal microscopy showed a low efficient cell seeding, particular for single layer scaffolds [Fig. 3(c), $48 \mathrm{~h}$ ]. However, over time the SCs, as happened with OECs, also successfully colonized the entire SPCL fibers [Fig. 3(c,d)], showing that these cells are capable to migrate and grow in a 3D manner on SPCL scaffolds. Finally, it was possible to confirm that cells reached the confluence at 2 weeks either in $90 / 1$ or in $90 / 2$ scaffolds, and there was a decrease in cell number at 3 weeks. All of the tests indicated that SCs culture on SPCL scaffolds with one or two layers should be implanted in animals after 2 weeks of in vitro culture.

The results presented in this work show that OECs and SCs could successfully grow and fully colonize both single and double SPCL scaffolds. In fact, in both cases there are some inconsistencies between the dsDNA assay and the metabolic activity of the cells. However, it is important to notice that as previously described by Hutmacher and coworkers $^{35}$ the quantification of metabolic activity in three dimensions cultures by MTS test cannot be directly compared with proliferations assays, such as the dsDNA assays. Actually, while the latter are based on the Picogreen assay, which is a sensitive test that can be correlated with proliferation of cells with time, MTS relies only in the capability of cells to metabolize MTS into a formazan salt, measuring the metabolic viability. This metabolic viability cannot be directly compared to cell proliferation as the cells own basal metabolism may be altered due to different parameters (such as: porosity, oxygen and nutrients availability, nature of the substrate where they are growing, etc.) that may or, may not, affect cell proliferation. Thus, it is possible to obtain different trends for both assays, which do not necessarily invalidate the results obtained from them, as they do measure different parameters when cells are growing in 3D scaffolds. In this sense, the results presented in our work show, for OECs, that after 3 weeks of culturing the use of $90 / 1$ or $90 / 2$ scaffolds will not significantly affect the 

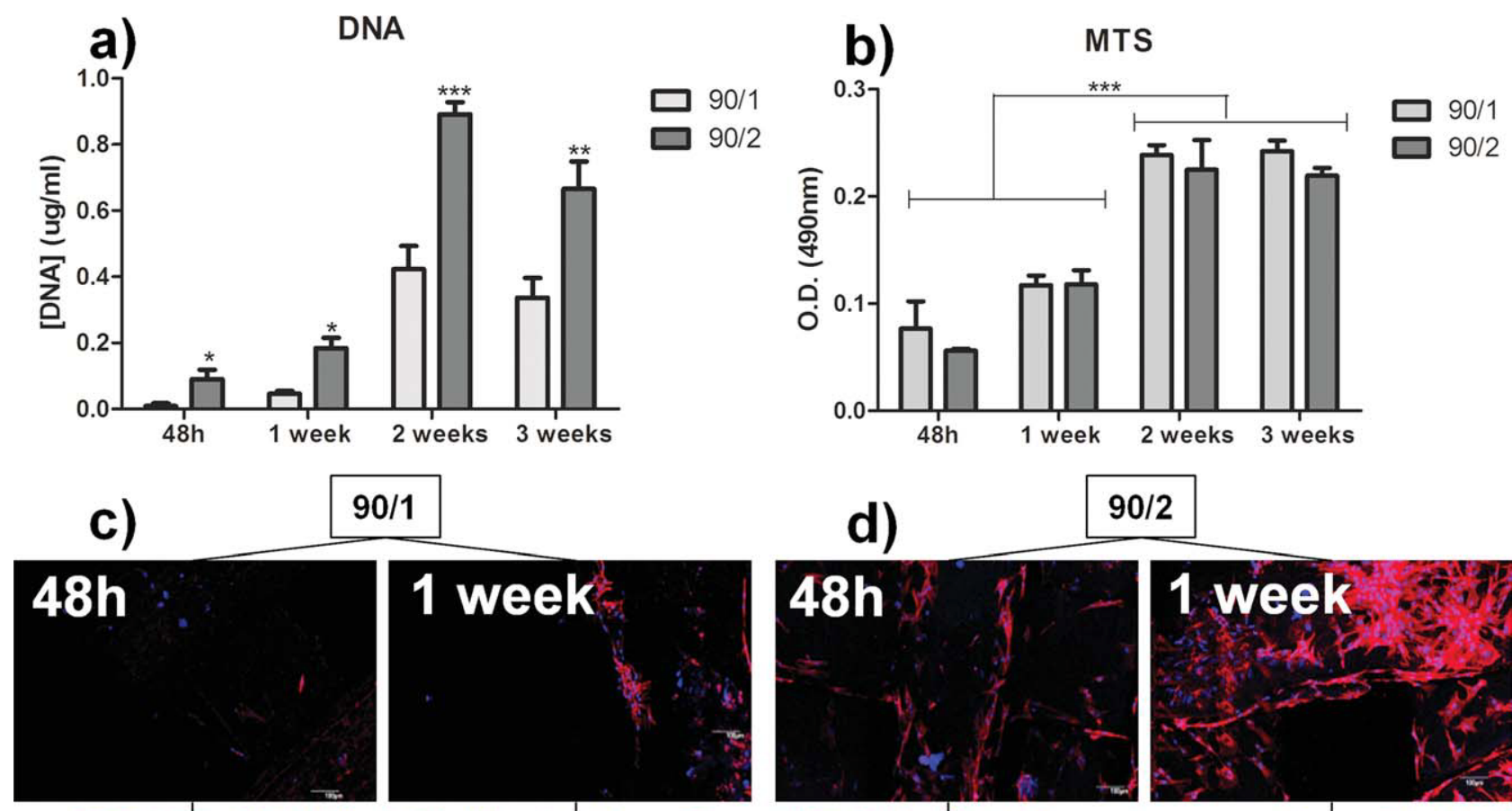

\section{$90 / 1$}
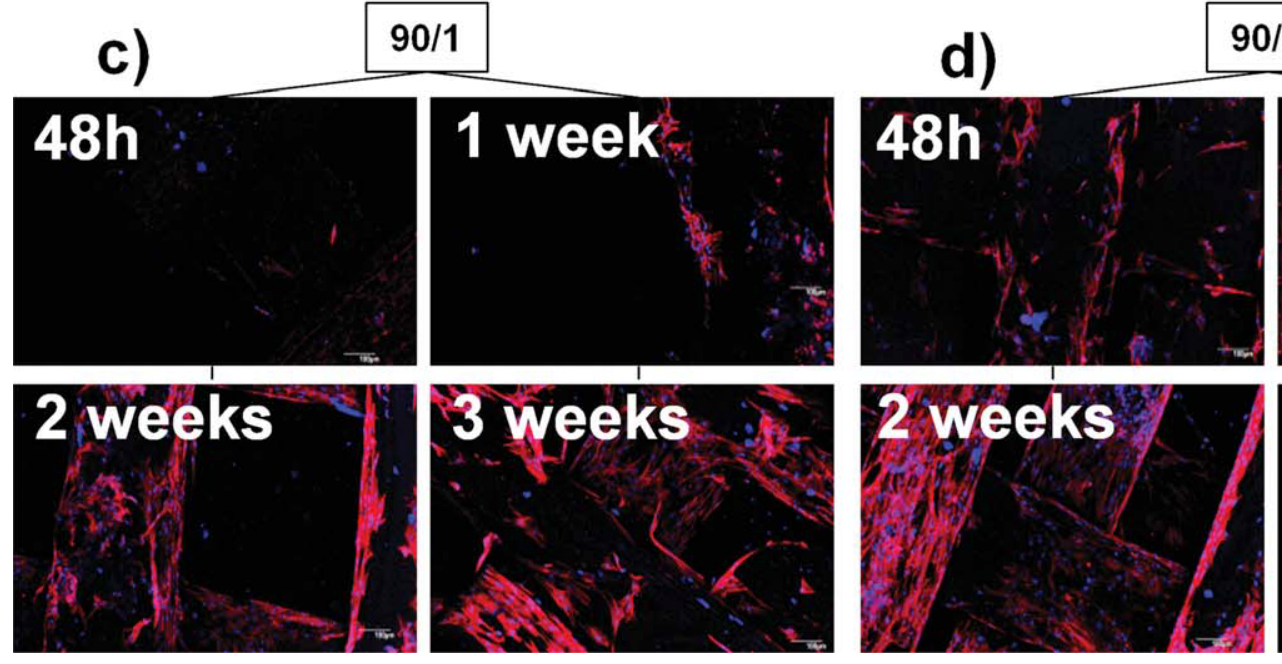

$90 / 2$
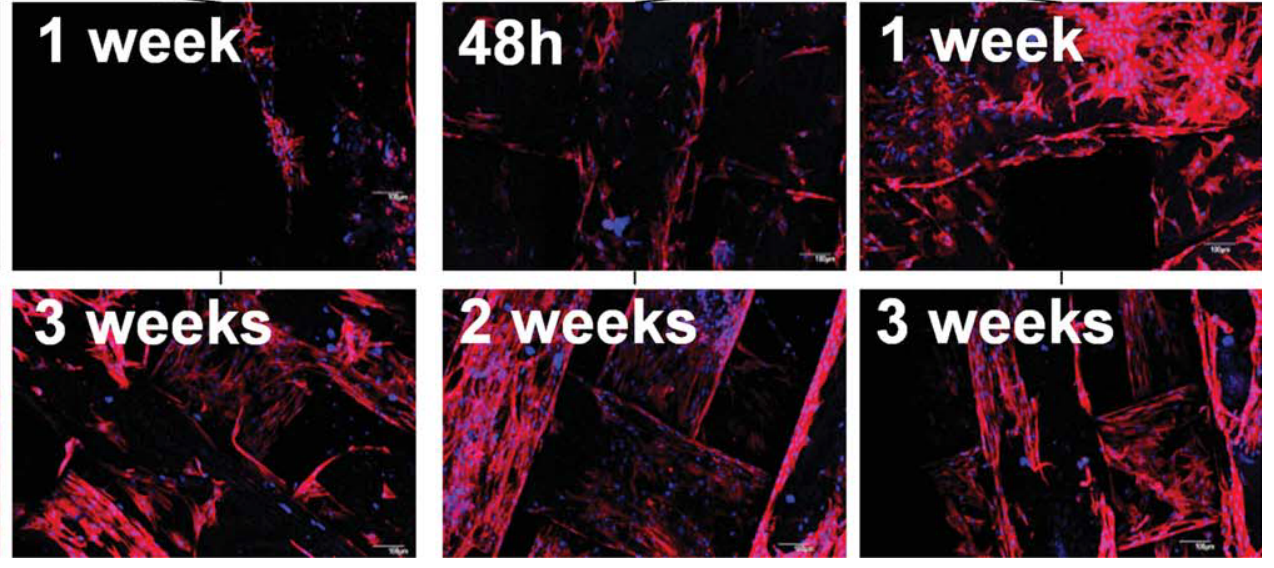

FIGURE 3. 3D cell culture of SCs on SPCL scaffolds. Both (a) cell proliferation and (b) metabolic activity analyses revealed a significant $(p<$ 0.05) overall increase over time. Confocal observation after cytoplasmic staining with phalloidin (red) and nuclei counterstained with DAPI (blue), revealed low efficient cell seeding (48 h) particular for single layer scaffolds (c) than for double layer (d). Over time, as happened with OECs, SCs were also able to migrate and colonize all fibers of both SPCL scaffolds. Values are shown as mean \pm SEM $(n=3)$. [Color figure can be viewed in the online issue, which is available at wileyonlinelibrary.com.]

number of the transplanted cells. However, for SCs the amount of dsDNA is always significantly higher in the $90 / 2$ scaffolds than in 90/1 ones. This means that for these cells it would be better to use the $90 / 2$ scaffolds for implantation. Concerning the metabolic activity, the results show some differences in the initial time points analyzed, and the cells reach the maximum activity after $2 / 3$ weeks of culture. Only in the last time points, it is possible to obtain similar results in the metabolic activity assay between single and double layers scaffolds. However, it is important to notice that the key time points for transplantation presented here can only be used for these scaffolds, since, most likely cells will respond in different ways to different polymers. Nonetheless, as happened with the starch-based scaffolds presented in this work, several others studies had shown either for OECs or SCs that these cells also need an initial time to adapt to scaffolds made from different origins. ${ }^{36-39}$ However, other studies, in which scaffolds were seeded with cells and implanted in animals just after a short preincubation in vitro of 1-2 days suggest the opposite. ${ }^{40-42}$ Nevertheless, it seems reasonable that the study of how cells behave on scaffolds should be performed at longer time points before the in vivo implantation, since the implanta- tion of a scaffold with a higher number of cells will most likely result in a higher number of cell survival and in this way, increase the cells' related effects on the implanted tissue.

\section{CONCLUSIONS}

Within this work, it was possible to demonstrate for the first time that a starch-based scaffold was able to support the growth and migration of OECs and SCs. Moreover, we demonstrated the importance of studying the long time in vitro incubation periods on the number of cells, which could be transplanted within the scaffold. For the structures here in studied, we demonstrated that 2 weeks of culture is the ideal time to reach a high number of transplantable cells. Further work will focus on the spine stabilization of SCI animals using SPCL scaffolds loaded with OECs, SCs, or a combination of both.

\section{REFERENCES}

1. Mathé $\mathrm{G}$, Jammet $\mathrm{H}$, Pendie N. Transfusions et greffes de moelle osseuse homologue chez des humaine irradies a haute dose accidentellement. Nouvelle Rev Franc Hematol 1959;4. 
2. Wyndaele M, Wyndaele JJ. Incidence, prevalence and epidemiology of spinal cord injury: What learns a worldwide literature survey? Spinal Cord 2006;44:523-529.

3. Lu J, Féron F, Mackay-Sim A, Waite PME. Olfactory ensheathing cells promote locomotor recovery after delayed transplantation into transected spinal cord. Brain 2002;125:14-21.

4. Santos-Benito FF, Ramón-Cueto A. Olfactory ensheathing glia transplantation: A therapy to promote repair in the mammalian central nervous system. Anat Rec B New Anat 2003;271:77-85.

5. Fouad K, Schnell L, Bunge MB, Schwab ME, Liebscher T, Pearse DD. Combining schwann cell bridges and olfactory-ensheathing glia grafts with chondroitinase promotes locomotor recovery after complete transection of the spinal cord. J Neurosci 2005;25:1169-1178.

6. Andrews MR, Stelzner DJ. Evaluation of olfactory ensheathing and schwann cells after implantation into a dorsal injury of adult rat spinal cord. J Neurotrauma 2007;24:1773-1792.

7. Lavdas AA, Chen J, Papastefanaki F, Chen S, Schachner M, Matsas $R$, Thomaidou $D$. Schwann cells engineered to express the cell adhesion molecule L1 accelerate myelination and motor recovery after spinal cord injury. Exp Neurol 2010;221:206-216.

8. Xu X, Onifer SM. Transplantation-mediated strategies to promote axonal regeneration following spinal cord injury. Respir Physiol Neurobiol 2009;169:171-182.

9. Wewetzer K, Verdú E, Angelov D, Navarro X. Olfactory ensheathing glia and Schwann cells: Two of a kind? Cell Tissue Res 2002; 309:337-345.

10. Zhang $\mathrm{N}, \mathrm{Yan} \mathrm{H}$, Wen $\mathrm{X}$. Tissue-engineering approaches for axonal guidance. Brain Res Rev 2005;49:48-64.

11. Huang HY, Chen L, Wang HM, Xiu B, Li BC, Wang R, Zhang J Zhang F, Gu Z, Li Y, Song YL, Hao W, Pang SY, Sun JZ. Influence of patients' age on functional recovery after transplantation of olfactory ensheathing cells into injured spinal cord injury. Chin Med J 2003;116:1488-1491.

12. Dobkin BH, Curt A, Guest J. Cellular transplants in China: Observational study from the largest human experiment in chronic spinal cord injury. Neurorehabil Neural Repair 2006;20:5-13.

13. Yasuda T, Weisel RD, Kiani C, Mickle DAG, Maganti M, Li R. Quantitative analysis of survival of transplanted smooth muscle cells with real-time polymerase chain reaction. J Thorac Cardiovasc Surg 2005;129:904-911

14. Hayashi M, Li T, Ito $\mathrm{H}$, Mikamo A, Hamano $\mathrm{K}$. Comparison of intramyocardial and intravenous routes of delivering bone marrow cells for the treatment of ischemic heart disease: An experimental study. Cell Transplant 2004;13:639-647.

15. Robey TE, Saiget MK, Reinecke H, Murry CE. Systems approaches to preventing transplanted cell death in cardiac repair. J Mol Cell Cardiol 2008;45:567-581.

16. Silva NA, Salgado AJ, Sousa RA, Oliveira JT, Pedro AJ, LeiteAlmeida $\mathrm{H}$, Cerqueira $\mathrm{R}$, Almeida A, Mastronardi F, Mano JF Neves NM, Sousa N, Reis RL. Development and characterization of a novel hybrid tissue engineering based scaffold for spina cord injury repair. Tissue Eng Part A 2010;16:45-54.

17. Silva NA, Sousa RA, Oliveira JT, Fraga JS, Fontes M, Cerqueira R, Leite-Almeida H, Almeida A, Sousa N, Reis RL, Salgado AJ. Moto improvements after spine stabilization of spinal cord injured rats with a novel 3D natural based biodegradable scaffold. Proceedings of the XII Meeting of Portuguese Society for Neurosciences, May, 2011; Lisbon, 206.

18. Woodhall E, West AK, Chuah MI. Cultured olfactory ensheathing cells express nerve growth factor, brain-derived neurotrophic factor, glia cell line-derived neurotrophic factor and their receptors. Mol Brain Res 2001;88:203-213.

19. Assouline JG, Bosch P, Lim R, Kim IS, Jensen R, Pantazis NJ. Rat astrocytes and Schwann cells in culture synthesize nerve growth factor-like neurite-promoting factors. Brain Res 1987;428:103-118.

20. Cao L, Mu L, Qiu Y, Su Z, Zhu Y, Gao L, Yuan Y, Guo D, He C. Diffusible, membrane-bound, and extracellular matrix factors from olfactory ensheathing cells have different effects on the selfrenewing and differentiating properties of neural stem cells. Brain Res 2010;1359:56-66.

21. Jiao Y, Novozhilova E, Karlén A, Muhr J, Olivius P. Olfactory ensheathing cells promote neurite outgrowth from co-cultured brain stem slice. Exp Neurol 2011;229:65-71.
22. Taylor JSH, Bampton ETW. Factors secreted by Schwann cells stimulate the regeneration of neonatal retinal ganglion cells. J Anat 2004;204:25-31.

23. Li Y, Field PM, Raisman G. Regeneration of adult rat corticospinal axons induced by transplanted olfactory ensheathing cells. J Neurosci 1998;18:10514-10524.

24. Li Y, Field PM, Raisman G. Repair of adult rat corticospinal tract by transplants of olfactory ensheathing cells. Science 1997;277: 2000-2002.

25. Papastefanaki F, Chen J, Lavdas AA, Thomaidou D, Schachner M, Matsas R. Grafts of Schwann cells engineered to express PSANCAM promote functional recovery after spinal cord injury. Brain 2007;130:2159-2174.

26. Ramón-Cueto A, Nieto-Sampedro M. Glial cells from adult rat olfactory bulb: Immunocytochemical properties of pure cultures of ensheathing cells. Neuroscience 1992;47:213-220.

27. Mauritz C, Grothe C, Haastert K. Comparative study of cell culture and purification methods to obtain highly enriched cultures of proliferating adult rat Schwann cells. J Neurosci Res 2004;77: 453-461.

28. Schofield GG. PicoGmeter, a custom-made fluorometer for the quantification of dsDNA by PicoGreen (R) fluorescence. Biotechniques 2004;37:778-782.

29. Zvibel I, Smets F, Soriano H. Anoikis: Roadblock to cell transplantation? Cell Transplant 2002;11:621-630.

30. Reddig P, Juliano R. Clinging to life: Cell to matrix adhesion and cell survival. Cancer Metastasis Rev 2005:24:425-439.

31. Hulsebosch CE. Recent Advances in pathophysiology and treatment of spinal cord injury. Adv Physiol Educ 2002;26:238-255.

32. Yang J, Yamato M, Kohno C, Nishimoto A, Sekine H, Fukai F, Okano T. Cell sheet engineering: Recreating tissues without biodegradable scaffolds. Biomaterials 2005;26:6415-6422.

33. Pirraco RP, Obokata $H$, Iwata $T$, Marques AP, Tsuneda S, Yamato $\mathrm{M}$, Reis $\mathrm{RL}$, Okano $\mathrm{T}$. Development of osteogenic cell sheets for bone tissue engineering applications. Tissue Eng Part A 2011;17:1507-1515.

34. Zhang M, Methot D, Poppa V, Fujio Y, Walsh K, Murry CE. Cardiomyocyte grafting for cardiac repair: Graft cell death and antideath strategies. J Mol Cell Cardiol 2001;33:907-921.

35. $\mathrm{Ng} \mathrm{KW}$, Leong DTW, Hutmacher DW. The challenge to measure cell proliferation in two and three dimensions. Tissue Eng 2005; 11:182-191.

36. Mollers S, Heschel I, Damink LH, Schugner F, Deumens R, Moller B, Bozkurt A, Nava JG, Noth J, Brook GA. Cytocompatibility of a novel, longitudinally microstructured collagen scaffold intended for nerve tissue repair. Tissue Eng Part A 2009:15:461-472.

37. Shen $Y$, Qian $Y$, Zhang $H$, Zuo B, Lu Z, Fan Z, Zhang $P$, Zhang F, Zhou C. Guidance of olfactory ensheathing cell growth and migration on electrospun silk fibroin scaffolds. Cell Transplant 2010;19:147-157.

38. Novikova LN, Pettersson J, Brohlin M, Wiberg M, Novikov LN. Biodegradable poly- $\beta$-hydroxybutyrate scaffold seeded with Schwann cells to promote spinal cord repair. Biomaterials 2008; 29:1198-1206.

39. Gupta D, Venugopal J, Prabhakaran MP, Dev VRG, Low S, Choon AT, Ramakrishna S. Aligned and random nanofibrous substrate for the in vitro culture of Schwann cells for neural tissue engineering. Acta Biomater 2009;5:2560-2569.

40. Oudega M, Gautier SE, Chapon P, Fragoso M, Bates ML, Parel J$M$, Bartlett Bunge M. Axonal regeneration into Schwann cell grafts within resorbable poly( $\alpha$-hydroxyacid) guidance channels in the adult rat spinal cord. Biomaterials 2001;22:1125-1136.

41. Hurtado A, Moon LDF, Maquet V, Blits B, Jérôme R, Oudega M. Poly (d,I-lactic acid) macroporous guidance scaffolds seeded with Schwann cells genetically modified to secrete a bi-functional neurotrophin implanted in the completely transected adult rat thoracic spinal cord. Biomaterials 2006;27: 430-442.

42. Moore MJ, Friedman JA, Lewellyn EB, Mantila SM, Krych AJ, Ameenuddin S, Knight AM, Lu L, Currier BL, Spinner RJ, Marsh RW, Windebank AJ, Yaszemski MJ. Multiple-channel scaffolds to promote spinal cord axon regeneration. Biomaterials 2006;27: 419-429. 